\title{
Improving the technology of uranium mining under the conditions of high groundwater pressure
}

\author{
Yernur Omarbekov ${ }^{1 * \otimes(0)}$, Khalidilla Yussupov ${ }^{1 \otimes(1)}$ \\ ${ }^{1}$ Satbayev University, Almaty, 50013, Kazakhstan \\ *Corresponding author: e-mail 13s_yernur88@mail.ru, tel.+77789567434
}

\begin{abstract}
Purpose. Substantiation of technological solutions for uranium mining by the method of In-Situ Leach Mining (ISL) under the conditions of the high groundwater pressure.

Methods. Analysis of mining-and-geological conditions of the deposit, conducting experimental-industrial works at the experimental unit, and processing data from research results. To increase the efficiency and reduce the expenditures for insitu leach mining of uranium, taking into account the hydrogeological peculiarities of the deposit, experimental works have been conducted using the "pumping wells" technology.

Findings. The proposed technology helps to reduce the expenditures for acquiring cable products, submersible pumps (the cost of a more powerful pump is much less than the cost of several ones, which are equal to it in power), for the construction of well heads. The dependences have been obtained of the change in the uranium content in the pregnant solution and the recovery coefficient on the L:S ratio (liquid to solid) using the "pumping wells" technology. With a change in L:S from 0.1 to 0.33 , the uranium content in the pregnant solution increases from 5 to $225 \mathrm{mg} / \mathrm{l}$, then its gradual decrease is observed. A change in L:S from 0.9 to 2.2 leads to an insignificant change in the uranium content to $100-120 \mathrm{mg} / \mathrm{l}$.

Originality. Based on the research results, the dependences have been obtained of the change in the uranium content in the pregnant solution and the recovery coefficient on the ratio of L:S using the "pumping wells" technology. The recovery coefficient has changed in direct proportion to the L:S ratio, hence, for L:S from 0.1 to 2 , the recovery coefficient increases from 1 to $87 \%$.
\end{abstract}

Practical implications. A new technology for uranium mining by the method of underground leaching has been developed, which is characterized by low capital expenditures and producing costs of in-situ leach mining of uranium.

Keywords: uranium, leaching, well, recovery

\section{Introduction}

World energy is one of the most important factors in the economic development of mankind. Today and in perspective, nuclear power plays and will play an important role in energy production, both in the world as a whole (16\% of the total annually generated electrical energy) and in economically developed countries, such as France (up to 75\%), Sweden $(38 \%)$, Finland $(33 \%)$, the USA (19\%), Great Britain (18\%), Russia (17\%), Canada (15\%), etc [1].

At the end of 2017, there were 448 thermal reactors operating in the world, with a total power of $392 \mathrm{GW}$, consuming about 60 thousand tons of natural uranium per year, which is close to its annual production. It is noted by World Nuclear Association in Madrid, that world nuclear power growth is at a 25-year high. During the period of 2015-2017, at an average 10 reactors were launched in the world per year, and in 2018, 14 new reactors were launched. It is supposed, that by 2050 the share of nuclear power in the world will reach $25 \%$, thereby preventing an increase in the average global temperature no more than by 2 degrees. According to Ux Consulting prediction, by 2020 , the number of reactors in the world will increase to 461 (power $-410 \mathrm{GW}$ ); prediction for 2030 533 reactors (power $-518 \mathrm{GW}$ )[2]-[8].

To provide such a large number of reactors, it is necessary to increase the uranium production by 2030 to 80 thousand tons, namely, by $25 \%$. Despite the depressing market, uranium mining is growing, and in 2016 it reached a record high of 62000 tons over the past 23 years. The main growth is provided by Kazakhstan, which has increased production over 10 years by more than 6 times. In 2018, $40 \%$ of the world's uranium was produced in Kazakhstan, which still remains the leader in the global mining of uranium [9]-[11].

About $25 \%$ of the world uranium reserves are in the bowels of Kazakhstan, and about $70 \%$ of them can be mined by the method of underground leaching [12][13]. Implementation of the industry development program initiated by the Government of the Republic of Kazakhstan made it possible 
to take first place in the world in uranium output, which in 2018 amounted to 21705 tons [14] with a deviation of $7 \%$ compared to 2017 (Fig. 1).

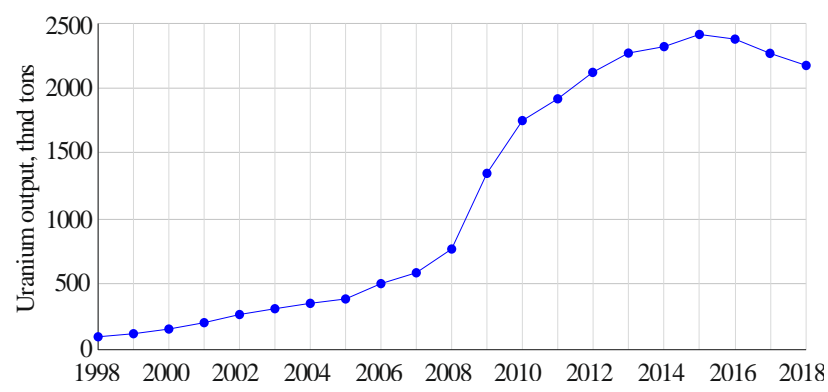

Figure 1. Uranium mining performance from 1998 to 2018

This achievement would be impossible without the implementation and improvement of the technology of in-situ leach mining of uranium, which has found wide application both in Kazakhstan [15]-[17] and in other countries [18], [19].

At present, underground leaching is one of the most promising methods for mining not only uranium, but a number of other rare and non-ferrous metals. When developing mineral deposits by the method of underground leaching, the deposit is under an impact at the place of its bedding in order to solubilize the useful components with their subsequent mining, which is usually carried out through wells drilled from the surface to the place of the deposit location [20][22].

Underground leaching is more reasonable and effective than traditional mining methods when developing poor deposits, as well as deep-seated deposits characterized by complex hydrogeological and mining-and-geological conditions [23]-[26]. Currently, about a quarter of all uranium is mined by the method of underground leaching [27].

During underground leaching of permeable ore bodies, a deposit is uncovered by a system of wells located (in plan) in rows, polygons, rings [28][29]. A leaching solution (solvent) is fed into the wells, which, being filtered through the seam, leaches useful components [30]-[32]. Pregnant solution is pumped out through other wells (Fig. 2).

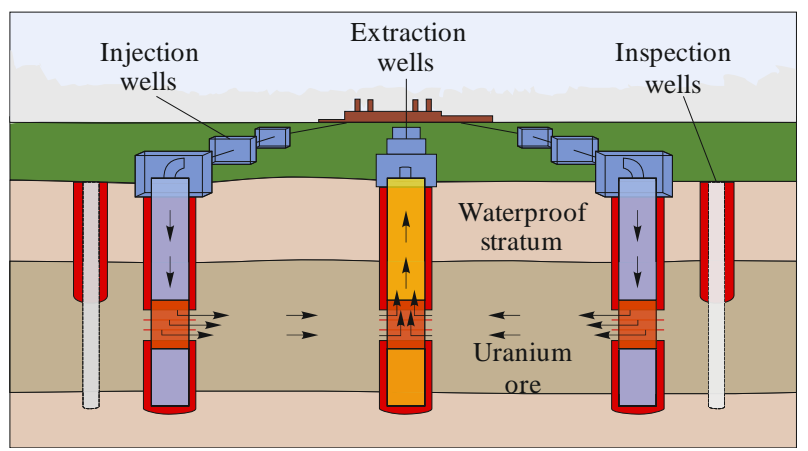

Figure 2. Scheme of uranium mining using the method of in-situ leach mining in wells

When using the method of underground leaching in wells, the projection of an ore deposit on the day surface determines the wells locations and the necessary infrastructure, as well as specified productivity of the processing complex, namely, the number of extraction and injection wells (Fig. 3).

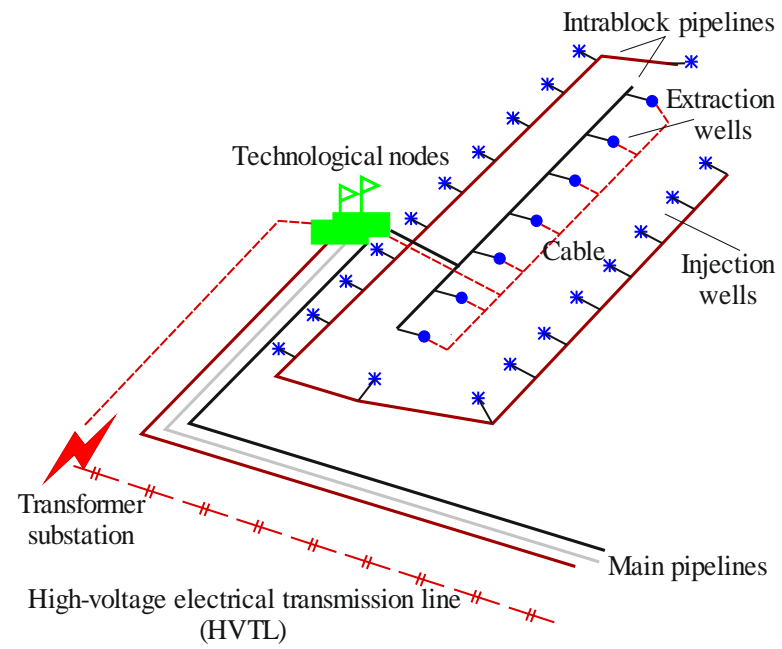

Figure 3. Scheme of the technological units binding

The technological wells binding is performed according to the traditional method, that is, a main pipeline for the leaching solution is conducted, from which the solution is distributed over the injection wells. For a pregnant solution, a main pipeline is also conducted into which the pregnant solution is supplied from the extraction wells.

The designs of the injection and extraction wells are different, since a submersible pump is located in the upper part of the extraction well. Therefore, a part of the well with a larger diameter is being drilled, then it is cased with pipes of larger size, and, correspondingly, the upper end of the well is equipped with a more expensive head. Electric cables are being laid to the place of the technological node location and to each such well from the transformer substation and from the solution distribution nodes [33]. As evidenced by the practice of the uranium deposits mining by the method of underground leaching in wells [34][35], on average there are 10 extraction wells and 30 injection wells in the unit. When the pump is operating in the extraction well, the maximum yield reaches up to $20 \mathrm{~m}^{3} / \mathrm{h}$, however, according to the technology regulation it should not exceed $12 \mathrm{~m}^{3} / \mathrm{h}$.

In the work [36], the authors present a method for increasing the efficiency of uranium mining from hydrogenous-type deposits using a plasma impulse excitation (PIE) onto the productive horizon. The peculiarity of the plasma impulse excitation method is the seam treatment of the producing unit with electro-hydraulic pulses created by a generator, which is placed in the filter part of the wells. However, the use of this method in order to intensify the uranium output in difficult mining-and-geological conditions with high seam pressure is ineffective. In addition, the placement of generators at each technological well will result in significant costs for production equipment maintenance.

The methods of uranium leaching using sulphuric acid as a leaching solution with the addition of hydrogen peroxide as an oxidizing agent are described in detail in the works [37][40], but in this case, the use of hydrogen peroxide is quite effective at small depths (150-250 m) of uranium bedding.

\section{Analysis of mining-and-geological conditions of the field}

At the Budyonovskoye uranium field, which is located in the Turkestan region of the Republic of Kazakhstan, the stratigraphic sequencing of the section is based on the princi- 
ples of periodicity and rhythm stratigraphy using data from log measurements, as well as paleontological age determination and analysis of the material composition of clays and sands. As shown in the figure, three horizons of the Upper Cretaceous (from bottom to top) are distinguished in the deposit area: Mynkuduksky, Inkuduksky and Zhalpaksky.

The Mynkuduksky horizon is uncovered by wells at depths of 410-790 $\mathrm{m}$ and is composed mainly of fine-grained light-grey sands with thin (up to $0.1 \mathrm{~m}$ ) layers of grey and dark-grey siltstones and clays. The share of coarse-grained varieties with gravel and alluvium accounts for $10-40 \%$ of the rock volume [41]. The horizon thickness is of 20-30 m. Oligomictic sands are mixed with polymictic material with film and pore cement (montmorillonite and kaolinite). Carbonate, ferrous and mangano-sideritic cement are rarely observed. The rocks contain carbonaceous organic matter ( $C_{\text {org }}$ from 0.01 to $1-5 \%$ ) in combination with iron sulphides. In the horizon roof, there is an increase in the content of the clay fraction and in the amount and thickness of clay and silty interlayers. The Inkuduksky horizon lies at depths of 330-720 m with washing-out, but without angular unconformity, as in Mynkuduk and sometimes directly on the rocks of Paleozoic basement [42].

The thickness of the macro rhythm is from 100 to $140 \mathrm{~m}$, on average of $120 \mathrm{~m}$, sometimes increasing to $150-160 \mathrm{~m}$ in areas of erosion cuttings into the underlying Mynkuduksky horizon. Three subhorizons are distinguished in the composition of Inkuduk in the deposit area: the lower and middle ones of approximately equal thickness, 50-60 m each. The boundary between them is traced by the lenticular interlayers of silts and clays of variable thickness.

The macro rhythm is composed, predominantly, of different-grained and coarse-grained sands with interlayers of fine-grained and gravel-alluvium formations. The share of coarse-grained rock accounts for 30-95\% of the total volume of the horizon. Quite rare thin (up to $0.5 \mathrm{~m}$ ) interlayers of dark-grey and mottled consolidated silts and clays occur. The rocks colour in the lower part of the horizon is mainly greycoloured, in the middle - mottled and in the upper part mottled-grey-coloured. In the lower part of the section, there are interlayers (up to $0.5 \mathrm{~m}$ ) of dense sandstones on carbonate cement. According to the mineralogical peculiarities, the Inkuduk rocks practically do not differ from the underlying Mynkuduk rocks [43][44].

The lower boundary of the horizon is quite clearly identified by the occurrence of coarse-grained deposit in the section, and the upper boundary is sometimes difficult to identify.

The waters of the horizon are under pressure. The piezometric level is located from $30 \mathrm{~m}$ above the earth surface in the northern part to its shallow occurrence (up to $23 \mathrm{~m}$ ) in the southern part.

Taking into account the geological and hydrogeological conditions of the ore-bearing horizon of the field No. 2 and the actual productivity of the extraction and injection wells, the extraction wells yield of the order of $10 \mathrm{~m}^{3} / \mathrm{h}$ is accepted for the technological units. Hence, the injection wells intake is $3.8: 4.3 \mathrm{~m}^{3} / \mathrm{h}$ [45][46].

The water level in the well is one of its main parameters that should be known to determine the yield and when choosing pumping equipment. There are static and dynamic level. The static water level is set in the well after idling time without pumping out for more than one hour [37] The essence of such a static position of the well is that the bottomhole pressure, that is, the pressure of the water column inside the well, balances the seam pressure, under which there is water in the water-bearing layer. Thus, equilibrium occurs and the water level stops rising. Under conditions of a positive dynamic level, experimental binding of units is used, which is shown in Figure 4 - schematic conditions for the applicability of pumps in wells, when the day surface marks can be higher (in practice) and lower than the dynamic level. Fundamentally, the schemes are the same and differ from each other only by marks of the day surface level [47].

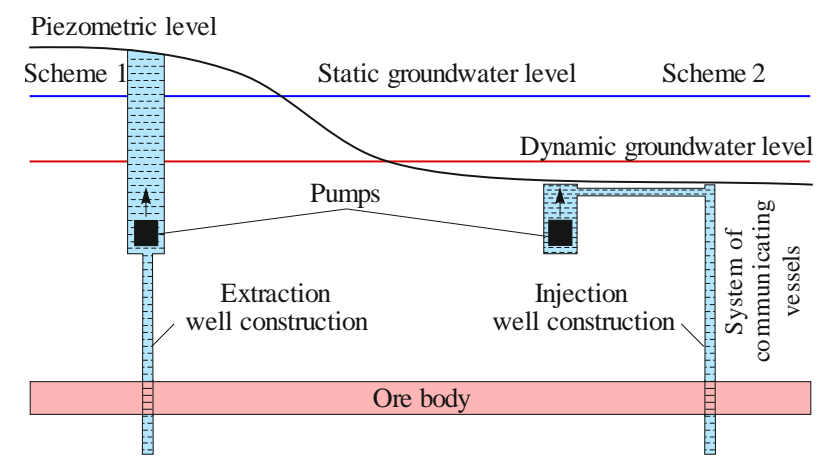

Figure 4. Scheme of the "pumping wells" application in various hydrodynamic systems

By analysing the mining-and-geological conditions of the field, it has been revealed that the mining technology is significantly influenced by the static groundwater level, which has a significant impact on the cost of pumping the pregnant solution. Currently, this factor is not taken into account in practice, as there are no studies on the static groundwater level. Thus, leaching of uranium in wells is conducted in the traditional way, which leads to excessive material expenditures.

\section{Methods}

To increase the efficiency and reduce the expenditures for underground leaching of uranium in wells, taking into account the hydrogeological peculiarities of the deposit, the experimental works are recommended to conduct using the "pumping wells" technology.

The alternative proposal is in the following: extraction wells should be constructed in the format of injection wells, that is, of the same diameter, without installing the pumps. Near the transformer substations, to the depth of 50-100 m, "pumping wells" are being drilled and equipped with a blank filterless string, in which the submersible pumps should be located. One such well is bound with several extraction wells. The total pumps power is equal to the optimal power at the traditional scheme of binding. Pumping wells with extraction wells are connected by hoses and are a system of communicating vessels. The main indicator, when conducting an experimental-industrial research, is the L:S ratio for various methods of mining [48][49].

The experimental unit is located at the "Karatau" mine, site No. 2. The unit area is $40500 \mathrm{~m}^{2}$, the ore is represented by solid rocks, the aquifer thickness is $8-12 \mathrm{~m}$, the occurrence depth is $650-710 \mathrm{~m}$. Average well depth is $690 \mathrm{~m}$, static groundwater level is from $+20 \mathrm{~m}$ and above the earth surface, dynamic groundwater level is up to $15 \mathrm{~m}$.

There are 30 injection wells and 14 extraction wells at the experimental unit, and the distance between the injection and extraction wells is 30 meters. The uncovering scheme by 
rows has been adopted. Drilling is performed by a BPU$1200 \mathrm{M}$ drilling rig (Mobile Drilling Unit).

Extraction wells are being constructed in the format of injection wells (Fig. 5), cased with a PVC pipe with a diameter of $89 \mathrm{~mm}$ and a filter - KDF 118 [50].

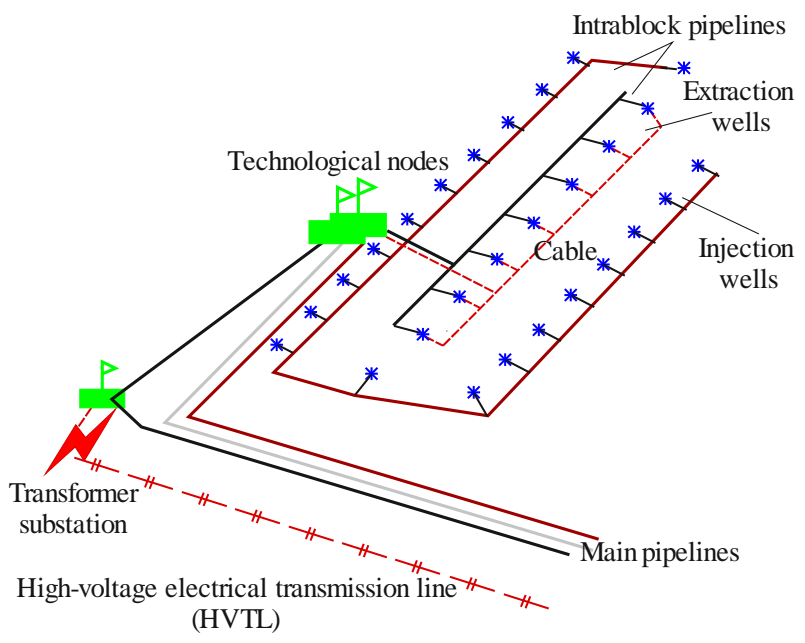

Figure 5. Experimental scheme of binding the unit
Taking into account the geological and hydrogeological conditions of the ore-bearing horizon of the field No. 2 and the actual productivity of the extraction and injection wells, the extraction wells yield of the order of $10 \mathrm{~m}^{3} / \mathrm{h}$ is accepted for the technological units. Hence, the injection wells intake is $3.8: 4.3 \mathrm{~m}^{3} / \mathrm{h}[51]$.

Geological, hydrogeological and geotechnological characteristics are known from the results of geological exploration or being determined during the calculations, except for one of the main geotechnological parameters - the L:S ratio [36]. When conducting experimental-industrial works, statistical data on changes in the uranium content in the pregnant solution and the recovery coefficient depending on the L:S ratio have been collected and processed both with the traditional technology and the proposed technology [52].

\section{Results and discussion}

Statistical data according to the traditional technology are presented in Table 1, and by the proposed technology - in Table 2. As can be seen from Table 1, a change in L:S from 0.1 to 0.27 leads to an increase in the uranium content in the pregnant solution from 5 to $700 \mathrm{mg} / \mathrm{l}$, namely, to the maximum value.

Table 1. Main indicators of the unit which is used in practice

\begin{tabular}{|c|c|c|c|c|c|c|c|c|c|}
\hline $\begin{array}{l}\mathrm{PS}^{*}, \\
\mathrm{~m}^{3} / \mathrm{h}\end{array}$ & $\begin{array}{l}\mathrm{LS}^{* *}, \\
\mathrm{~m}^{3} / \mathrm{h}\end{array}$ & $\begin{array}{l}\text { Uranium content } \\
\text { in PS, mg/l }\end{array}$ & Acidity, g/l & $\begin{array}{l}\mathrm{pH}^{* * * *}, \\
\mathrm{pH} \text { units }\end{array}$ & $\begin{array}{c}\mathrm{Eh}^{* * * * *}, \\
\mathrm{mV}\end{array}$ & $\mathrm{H}_{2} \mathrm{SO}_{4}$ in PS & $\mathrm{L} / \mathrm{S}^{* * * * * *}$ & $\begin{array}{c}\mathrm{PS}, \\
\mathrm{m}^{3} / \text { day }\end{array}$ & $\begin{array}{c}\mathrm{LS}, \\
\mathrm{m}^{3} / \text { day }\end{array}$ \\
\hline 117 & 121 & 2 & 25 & 6.6 & 67 & 0.00 & 0.00 & 2799 & 2909 \\
\hline 114 & 106 & 2 & 25 & 5.8 & 188 & 0.00 & 0.01 & 2731 & 2553 \\
\hline 109 & 86 & 2 & 25 & 6.0 & 80 & 0.00 & 0.01 & 2622 & 2055 \\
\hline 83 & 124 & 2 & 25 & 6.0 & 79 & 0.00 & 0.01 & 2000 & 2979 \\
\hline 119 & 139 & 2 & 25 & 6.8 & 47 & 0.00 & 0.01 & 2849 & 3341 \\
\hline 146 & 148 & 2 & 25 & 7.2 & 122 & 0.00 & 0.02 & 3494 & 3541 \\
\hline 150 & 168 & 4 & 25 & 6.7 & 126 & 0.00 & 0.02 & 3601 & 4036 \\
\hline 142 & 140 & 4 & 20 & 6.5 & 101 & 0.00 & 0.02 & 3402 & 3352 \\
\hline 142 & 148 & 4 & 20 & 6.7 & 98 & 0.00 & 0.03 & 3419 & 3546 \\
\hline 146 & 148 & 5 & 20 & 6.2 & 90 & 0.00 & 0.03 & 3507 & 3547 \\
\hline 144 & 146 & 4 & 20 & 6.2 & 141 & 0.00 & 0.03 & 3459 & 3503 \\
\hline 152 & 151 & 3 & 20 & 6.3 & 76 & 0.00 & 0.04 & 3650 & 3625 \\
\hline 146 & 148 & 4 & 20 & 5.9 & 140 & 0.00 & 0.04 & 3497 & 3556 \\
\hline 149 & 152 & 4 & 20 & 5.6 & 199 & 0.00 & 0.04 & 3570 & 3638 \\
\hline 149 & 151 & 4 & 20 & 4.6 & 314 & 0.00 & 0.05 & 3576 & 3635 \\
\hline 146 & 149 & 4 & 15 & 4.4 & 331 & 0.00 & 0.05 & 3513 & 3585 \\
\hline 142 & 144 & 4 & 15 & 3.7 & 377 & 0.00 & 0.06 & 3415 & 3444 \\
\hline 147 & 150 & 5 & 15 & 3.3 & 437 & 0.00 & 0.06 & 3522 & 3597 \\
\hline 117 & 121 & 2 & 25 & 6.6 & 67 & 0.00 & 0.00 & 2799 & 2909 \\
\hline
\end{tabular}

*Pregnant solution (PS) - a solution formed in the bowels as a result of physical-chemical interaction of the leaching solution with minerals of ores and host rocks of the productive horizon and containing minerals with a concentration above the industrial minimum.

${ }^{* *}$ Leaching solution (LS) - a solution containing reagents necessary for extracting a useful component and supplied to injection wells.

${ }^{* * * *}$ Hydrogen-ion exponent $(\mathrm{pH})$ - a value characterizing the concentration of hydrogen ions in solutions, which is numerically equal to the negative decimal logarithm of the $\mathrm{H}^{+}$ions concentration expressed in gram-ions per litre: $\mathrm{pH}=-\lg \left[\mathrm{H}^{+}\right]$.

${ }^{* * * * *}$ Oxidation-reduction potential $(\mathrm{Eh})$ - measure of the chemical activity of elements or their compounds in reversible chemical processes connected with a change in the charge of ions in the solutions [53].

${ }^{* * * * * *} \mathrm{~L}: \mathrm{S}$ ratio - the amount of leaching solution per weight unit of leachable ore-mining mass, providing a specified extraction of mineral resources, dimensionless value.

Then, a sharp its decrease is observed. With a change in $\mathrm{L}: \mathrm{S}$ from 1.1 to 2.8 , there is an insignificant change in the uranium content to $100-120 \mathrm{mg} / \mathrm{l}$. The recovery coefficient varies in direct proportion to the $\mathrm{L}: \mathrm{S}$ ratio. Thus, when changing $\mathrm{L}: \mathrm{S}$ from 0.1 to 2.8 , the recovery coefficient increases from $1 \%$ to $105 \%$. The recovery coefficient of $105 \%$, exceeding $100 \%$, is explained by the incorrect calculation of uranium reserves, that is, it turned out that there are more actual reserves.
As can be seen from Table 2, with a change in L:S from 0.1 to 0.33 , the uranium content in the pregnant solution increases from 5 to $225 \mathrm{mg} / \mathrm{l}$, and then it gradually decreases. With a change in L:S from 0.9 to 2.2 , there is an insignificant change in the uranium content to $100-120 \mathrm{mg} / \mathrm{l}$. The recovery coefficient is changed in direct proportion to the $\mathrm{L}: \mathrm{S}$ ratio. Thus, when changing L:S from 0.1 to 2.2 , the recovery coefficient increases from 1 to $87 \%$. 
Table 2. Main indicators of the experimental unit

\begin{tabular}{|c|c|c|c|c|c|c|c|c|c|}
\hline $\mathrm{PS}, \mathrm{m}^{3} / \mathrm{h}$ & $\begin{array}{l}\mathrm{LS}, \\
\mathrm{m}^{3} / \mathrm{h}\end{array}$ & $\begin{array}{l}\text { Uranium content } \\
\text { in PS, mg/l }\end{array}$ & Acidity, $\mathrm{g} / \mathrm{l}$ & $\begin{array}{c}\mathrm{pH}, \\
\mathrm{pH} \text { units }\end{array}$ & $\begin{array}{l}\text { Eh, } \\
\mathrm{mV}\end{array}$ & $\mathrm{H}_{2} \mathrm{SO}_{4}$ in PS & $\mathrm{L} / \mathrm{S}$ & $\begin{array}{c}\mathrm{PS}, \\
\mathrm{m}^{3} / \text { day }\end{array}$ & $\begin{array}{c}\text { LS, } \\
\mathrm{m}^{3} / \text { day }\end{array}$ \\
\hline 117 & 121 & 2 & 25 & 6.6 & 67 & 0.00 & 0.00 & 2799 & 2909 \\
\hline 114 & 106 & 2 & 25 & 5.8 & 188 & 0.00 & 0.01 & 2731 & 2553 \\
\hline 109 & 86 & 2 & 25 & 6.0 & 80 & 0.00 & 0.01 & 2622 & 2055 \\
\hline 83 & 124 & 2 & 25 & 6.0 & 79 & 0.00 & 0.01 & 2000 & 2979 \\
\hline 119 & 139 & 2 & 25 & 6.8 & 47 & 0.00 & 0.01 & 2849 & 3341 \\
\hline 146 & 148 & 2 & 25 & 7.2 & 122 & 0.00 & 0.02 & 3494 & 3541 \\
\hline 150 & 168 & 4 & 25 & 6.7 & 126 & 0.00 & 0.02 & 3601 & 4036 \\
\hline 142 & 140 & 4 & 20 & 6.5 & 101 & 0.00 & 0.02 & 3402 & 3352 \\
\hline 142 & 148 & 4 & 20 & 6.7 & 98 & 0.00 & 0.03 & 3419 & 3546 \\
\hline 146 & 148 & 5 & 20 & 6.2 & 90 & 0.00 & 0.03 & 3507 & 3547 \\
\hline 144 & 146 & 4 & 20 & 6.2 & 141 & 0.00 & 0.03 & 3459 & 3503 \\
\hline 152 & 151 & 3 & 20 & 6.3 & 76 & 0.00 & 0.04 & 3650 & 3625 \\
\hline 146 & 148 & 4 & 20 & 5.9 & 140 & 0.00 & 0.04 & 3497 & 3556 \\
\hline 149 & 152 & 4 & 20 & 5.6 & 199 & 0.00 & 0.04 & 3570 & 3638 \\
\hline 149 & 151 & 4 & 20 & 4.6 & 314 & 0.00 & 0.05 & 3576 & 3635 \\
\hline 146 & 149 & 4 & 15 & 4.4 & 331 & 0.00 & 0.05 & 3513 & 3585 \\
\hline 142 & 144 & 4 & 15 & 3.7 & 377 & 0.00 & 0.06 & 3415 & 3444 \\
\hline 147 & 150 & 5 & 15 & 3.3 & 437 & 0.00 & 0.06 & 3522 & 3597 \\
\hline 145 & 148 & 6 & 15 & 3.2 & 441 & 0.00 & 0.06 & 3488 & 3546 \\
\hline
\end{tabular}

The processing of the data in Table 1 made it possible to obtain the dependences of the changes in the uranium content in the pregnant solution and the recovery coefficient on the $\mathrm{L}: \mathrm{S}$ ratio according to the traditional technology (Fig. 6). Important indexes: Extraction of $\mathrm{Me}-541$ thnd $\mathrm{kg}$; ore material - 977 thnd ton; number of injection wells - 15; number of extraction wells -41 .

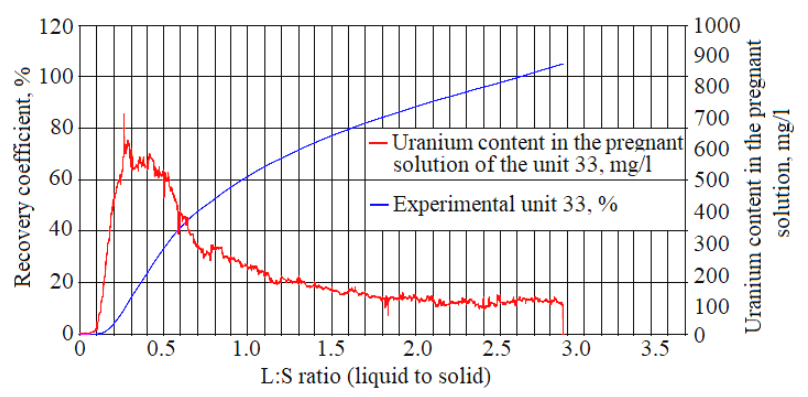

Figure 6. Actual schedule of extraction and quality (content) of Me in the solutions according to the technology used in practice

The processing of the data in Table 2 made it possible to obtain the dependences of the changes in the uranium content in the pregnant solution and the recovery coefficient on the $\mathrm{L}: \mathrm{S}$ ratio according to the proposed technology (Fig. 7).

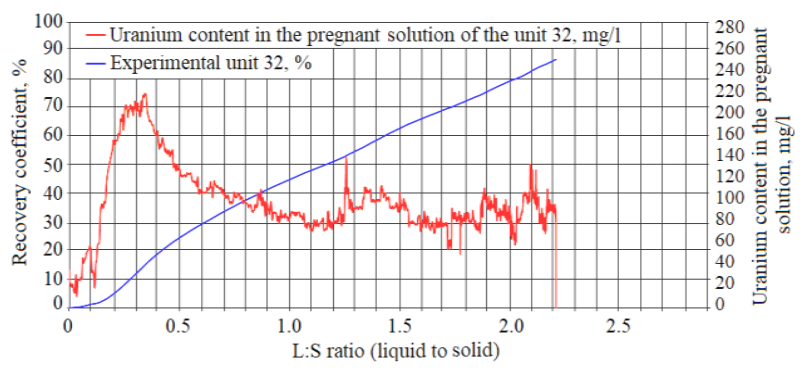

Figure 7. Actual schedule of extraction and quality (content) of Me in the solutions according to the experimental technology

As a result of implementing the proposed "pumping wells" technology, there is no need to drill the extraction wells of large diameter for installing pumps, since they are constructed in the format of injection wells, namely, of the same diameter, without installing pumps. This reduces the expenditures for drilling operations, as well as for the extraction wells construction. The number of such pumping wells per technological unit is determined with account of the static groundwater level, which reduces the expenditures for the purchase and installation of submersible pumps (the cost of a more powerful pump is much less than the cost of several ones, which are equal to it in power). Due to the location of the "pumping wells" near the transformer substation, the expenditures for purchasing cable products are reduced.

When comparing the unit used in practice and the experimental one, it is evident that the main geotechnological parameters, such as the degree of the useful component extraction, the L:S value, the reagent specific consumption, the concentration of the extracted component in the solution and the leaching time, do not worsen the efficiency of underground leaching in wells.

In the future, the authors set the task to conduct theoretical and experimental-industrial studies for determining the number of pumping wells and pumps power, taking into account the initial static groundwater level and the subsequent decrease in the static level as ore reserves are mined, as well as study the optimal number of pumping wells for efficiency of uranium leaching process.

\section{Conclusions}

Based on experimental-industrial tests of the "pumping wells" technology and processing of the obtained data, the following conclusions can be drawn.

1. The Budyonovskoye field differs from other fields in the high static groundwater level. Despite this fact, the traditional parameters, as well as the diagrams of lay-out and binding of test sites are used at the field, which leads to excessive material and labour expenditures.

2. A necessary requirement for applying the "pumping wells" technology is the positive pressure of groundwater above the day surface (self-discharge) and the location of the pump below the dynamic level. The number of such pumping wells per technological unit is determined with account of the static groundwater level. 
3. The dependences have been obtained of the change in the uranium content in the pregnant solution and the recovery coefficient on the L:S ratio when using the "pumping wells" technology.

4. Conducted experimental-industrial works have substantiated the efficiency of the "pumping wells" technology application in the conditions of the Budyonovskoye field.

\section{Acknowledgements}

The authors of the paper are grateful to A.I. Matunov, Deputy General Director for Geology and Subsoil Use of JV Budyonovskoye LLP, for rendering a valuable advice and assistance in collecting statistical data.

\section{References}

[1] World energy outlook. (2019). International Energy Agency. https://doi.org/10.1787/caf32f3b-en

[2] Mounfield, P.R. (2017). World nuclear power. Routledge. https://doi.org/10.4324/9781315141657

[3] Hore-Lacy, I. (2010). Nuclear energy in the $21^{\text {st }}$ century. World Nuclear University Press, Elsevier.

[4] Zubkova, V., Strojwas, A., Bielecki, M., Kieush, L., \& Koverya, A. (2019). Comparative study of pyrolytic behavior of the biomass wastes originating in the Ukraine and potential application of such biomass. Part 1. Analysis of the course of pyrolysis process and the composition of formed products. Fuel, (254), 115688. https://doi.org/10.1016/j.fuel.2019.115688

[5] Mounfield, P.R. (2017). The world pattern of nuclear power production. World Nuclear Power, 28-62. https://doi.org/10.4324/9781315141657-3

[6] Hansen, J., Sato, M., Ruedy, R., Lo, K., Lea, D.W., \& MedinaElizade, M. (2006). Global temperature change. Proceedings of the $\mathrm{Na}$ tional Academy of Sciences, 103(39), 14288-14293. https://doi.org/10.1073/pnas.0606291103

[7] Ruela, R., Sousa, M.C., deCastro, M., \& Dias, J.M. (2020). Global and regional evolution of sea surface temperature under climate change. Global and Planetary Change, (190), 103190. https://doi.org/10.1016/j.gloplacha.2020.103190

[8] Kieush, L. (2019). Coal pyrolysis products utilisation for synthesis of carbon nanotubes. Petroleum and Coal, 61(3), 461-466.

[9] Kalyuzhnova, Y., \& Pomfret, R. (2017). Sustainable energy in Kazakhstan: Moving to cleaner energy in a resource-rich country (pp. 1-286). https://doi.org/10.4324/9781315267302

[10] Karatayev, M., \& Clarke, M.L. (2014). Current energy resources in Kazakhstan and the future potential of renewables: A review. Paper presented at the Energy Procedia, (59), 97-104. https://doi.org/10.1016/j.egypro.2014.10.354

[11] Rakishev, B.R. (2017). Technological resources for improving the quality and completeness of use of the mineral raw materials. News of the National Academy of Sciences of the Republic of Kazakhstan, Series of Geology and Technical Sciences, 2(422), 116-124.

[12] Kazakhstan to become key uranium player. (2005). Nuclear Engineering International, 50(617), 3.

[13] Transportation - quick takes: China, Kazakhstan sign accords for gas, uranium. (2010). Oil and Gas Journal, 108(25), 11.

[14] Vypolnyaya obeshchaniya. Sozdavaya stoimost'. (2018). Godovoy otchet. AO "NAK "Kazatomprom".

[15] Rakishev, B.R., Mataev, M.M., \& Kenzhetaev, Z.S. (2019). Analysis of mineralogical composition of sediments in in-situ leach mining of uranium. Mining Informational and Analytical Bulletin, (7), 123-131. https://doi.org/10.25018/0236-1493-2019-07-0-123-131

[16] Kuznetsova, A., Doulala-Rigby, C., Solovyev, G., \& Orlov, E. (2017). Implication of the mechanically stabilised granular layer for access road over saline soils at uranium in situ leaching mine in South Kazakhstan. Bearing Capacity of Roads, Railways and Airfields, 11211126. https://doi.org/10.1201/9781315100333-150

[17] Takenouchi, S. (1996). Sandstone-type uranium deposits in Kazakhstan - in connection with in-situ leaching method. Resource Geology, 46(4), 233-243.

[18] Abzalov, M.Z., Drobov, S.R., Gorbatenko, O., Vershkov, A.F., Bertoli, O., Renard, D., \& Beucher, H. (2014). Resource estimation ofin situleach uranium projects. Applied Earth Science, 123(2), 71-85. https://doi.org/10.1179/1743275814y.0000000055
[19] Mudd, G. (2001). Critical review of acid in situ leach uranium mining: 1. USA and Australia. Environmental Geology, 41(3-4), 390-403. https://doi.org/10.1007/s002540100406

[20] Zhou, Q.S., \& Li, Z.Y. (2003). Geological characteristics and ore prospects of underground leaching sandstone-type uranium deposits on the southwestern margin of the Turpan-Hami basin. Geology in China, 30(2), 186-191.

[21] Shatalov, V.V., Fazlullin, M.I., Romashkevich, R.I., Smirnova, R.N., \& Adosik, G.M. (2001). Ecological safety of underground leaching of uranium. Atomic Energy, 91(6), 1009-1015. https://doi.org/10.1023/a:1014815705034

[22] Golik, V.I., Razorenov, Y.I., \& Lyashenko, V.I. (2018). Conditions of leaching non-ferrous metals from non-commercial reserves. Bulletin of the Tomsk Polytechnic University, Geo Assets Engineering, 329(6), 6-16.

[23] Mudd, G. (2001). Critical review of acid in situ leach uranium mining: 2. Soviet Block and Asia. Environmental Geology, 41(3-4), 404-416. https://doi.org/10.1007/s002540100405

[24] Wadden, D., \& Gallant, A. (1985). The in-place leaching of uranium at Denison mines. Canadian Metallurgical Quarterly, 24(2), 127-134. https://doi.org/10.1179/cmq.1985.24.2.127

[25] Lietava, P. (2000). Risk-assessment model for evaluating environmental remediation options at the Stráž underground uranium leaching site. The Environmental Challenges of Nuclear Disarmament, 191-204. https://doi.org/10.1007/978-94-011-4104-8_23

[26] Chekmarev, A.M., Troshkina, I.D., Nesterov, Y.V., Maiboroda, A.B., Ushanova, O.G., \& Smirnov, N.S. (2004). Associated rhenium extraction in complex processing of productive solutions of underground uranium leaching. Chemistry for Sustainable Development, (12), 113-117.

[27] Rodionov, V.G. (2010). Energetika: problemy nastoyashchego $i$ vozmozhnosti budushchego. Moskva, Rossiya: ENAS.

[28] Catchpole, M., \& Robins, W. (2015). Future global energy demand. AusIMM Bulletin.

[29] Sondor, D.V. (2014). Uran: zapasy, dobycha, perspektivy, problemy. Sostoyanie i puti razvitiya rossiyskoy energetiki. Tomsk, Rossiya: Skan.

[30] Aben, E., Markenbayev, Z., Khairullaev, N., Myrzakhmetov, S., \& Aben, K. (2019). Study of change in the leaching solution activity after treatment with a cavitator. Mining of Mineral Deposits, 13(4), 114-120. https://doi.org/10.33271/mining13.04.114

[31] Slezak, J. (2008). Uranium ISL mining activities at the international atomic energy agency. Uranium, Mining and Hydrogeology, 1-10. https://doi.org/10.1007/978-3-540-87746-2_1

[32] Yusupov, Kh.A., \& Dzhakupov, D. (2017). Issledovanie primeneniya biftorida ammoniya dlya khimicheskoy obrabotki skvazhin. Gornyy Zhurnal, (4), 57-59.

[33] Omarbekov, E.U, El'zhanov, E.A， \& Myrzakhmetov, S.S. (2017). Sovershenstvovanie tekhnologii pri dobyche urana metodom PSV. Nauchnoe $i$ Kadrovoe Soprovozhdenie Innovatsionnogo Razvitiya Gorno-Metallurgicheskogo Kompleksa, 60-62.

[34] Lyashenko, V.I., Franchuk, V.P., \& Kisly, B.P. (2015). Reengineering of technical-and-technological structure of uranium mine. Gornyi Zhurnal, (1). https://doi.org/10.17580/gzh.2015.01.05

[35] Lyashenko, V.I. (2005). Environment and resource saving methods of inventory control of uranium mines and deposits. Metallurgicheskaya $i$ Gornorudnaya Promyshlennost, (1), 122-127.

[36] Molchanov, A.A., \& Demekhov, Yu.V. (2014). Povyshenie effektivnosti dobychi urana iz mestorozhdeniy gidrogennogo tipa, razrabatyvaemykh metodom podzemnogo skvazhinnogo vyshchelachivaniya Respubliki Kazakhstan (na primere mestorozhdeniya vostochnyy Mynkuduk). Aktual'nye Problemy Uranovoy Promyshlennosti, 92-98.

[37] Khawassek, Y., Taha, M., \& Eliwa, A. (2016). Kinetics of leaching process using sulfuric acid for Sella uranium ore material, South Eastern Desert, Egypt. International Journal of Nuclear Energy Science and Engineering, 6(0), 62. https://doi.org/10.14355/ijnese.2016.06.006

[38] Filippov, A.P., \& Nesterov, Yu.V. (2001). Lignosul'fonat ammoniya dobavka, intensifitsiruyushchaya sernokislotnoe vyshchelachivanie urana iz rud. Khimicheskaya Tekhnologiya, (8), 21-25.

[39] Panteleev, V.M. (2002). Ful'vokislotnyy rastvoritel' dlya podzemnogo i kuchnogo vyshchelachivaniya urana (povysheniya effektivnosti proizvodstva ekologicheski bezopasnymi sposobami). Moskva, Rossiya: Nedra.

[40] Kanevskiy, E.A., Filipov, A.P., \& Vel'matkin, M.I. (1963). Optimal'naya oblast' $\mathrm{pH}$ pri sernokislotnom rastvorenii dvuokisi urana s uchastiem razlichnykh okisliteley i ionov Fe(II). Radiokhimiya, 5(6), 1-7.

[41] Golik, V.I., \& Kultyshev, V.I. (2011). Istoriya i perspektivy vyshchelachivaniya urana. Gornyy Informatsionno-Analiticheskiy Byulleten', (7), 138-143.

[42] Yashin, S.A. (2008). Podzemnoe skvazhinnoe vyshchelachivanie urana na mestorozhdeniyakh Kazakhstana. Gornyy Zhurnal, (3), 45-49. 
[43] Ismailov, T.T., Golik, V.I., \& Dol'nikov, E.B. (2008). Spetsial'nye sposoby razrabotki mestorozhdeniy poleznykh iskopaemykh. Moskva, Rossiya: Izdatel'stvo Moskovskogo gosudarstvennogo gornogo universiteta.

[44] Golik, V.I., \& Kultyshev, V.I. (2011). Istoriya i perspektivy vyshchelachivaniya urana. Gornyy Informatsionno-Analiticheskiy Byulleten', (7), 138-143

[45] Bekman, I.N. (2009). Uranovoe proizvodstvo. Moskva, Rossiya: Moskovskiy gosudarstvennyy universitet im. M.V. Lomonosova.

[46] Rukin, A.A. (2017). Tekhnologiya i tekhnika bureniya razvedochnoekspluatatsionnykh skvazhin na uran na uchastke "Zhalpakskom" (p. Kyzemshek Yuzhno-Kazakhstanskaya oblast'). Tomsk, Rossiya: Institut prirodnykh resursov.

[47] Khan, Y., Sakhawat, S., \& Muhammad, S. (2012). Selection of lixiviante system for the alkaline in situ leaching of uranium from an arkosic type of sandstone and measuring the dissolution behavior of some metals and nonmetals. Journal Chemical Society of Pakistan, (34), 826-840.

[48] Malukhin, N.G., \& Markelov, S.V. (2011). Obosnovanie ratsional'noy oblasti primeneniya tekhnologii podzemnogo vyshchelachivaniya glinistykh uranovykh rud. Gornyy Informatsionno-Analiticheskiy Byulleten', (10), 223-225.

\section{Удосконалення технології видобутку урану} в умовах високонапірного характеру підземних вод

\section{Е. Омарбеков, Х. Юсупов}

Мета. В умовах високонапірного характеру підземних вод обгрунтувати технологічні рішення видобутку урану методом підземного свердловинного вилуговування

Методика. Аналіз гірничо-геологічних умов родовища, проведення дослідно-промислових робіт на експериментальному блоці, оброблення даних результатів досліджень. Для підвищення ефективності та зниження витрат на підземне свердловинне вилуговування урану з урахуванням гідрогеологічних особливостей родовища були проведені експериментальні роботи із застосуванням технології “насосних свердловин”.

Результати. Запропонована технологія призводить до зниження витрат на закупівлю кабельної продукції, занурених насосів (вартість більш потужного насоса набагато менше, ніж вартість декількох, рівних йому за потужністю), на спорудження оголовників свердловин. Отримано залежності зміни вмісту урану в продуктивному розчині та коефіцієнта вилучення від співвідношення P:Т (рідкого до твердого) при технології “насосних свердловин” зі зміною Р:Т від 0.1 до 0.33 , вміст урану в продуктивному розчині зріс від 5 до 225 мг/л, далі спостерігається його плавне зниження. Зміна Р:Т від 0.9 до 2.2 призводить до незначної зміни вмісту урану до 100-120 мг/л.

Наукова новизна. В результаті проведених досліджень отримані залежності зміни вмісту урану в продуктивному розчині та коефіцієнта вилучення від співвідношення Р:Т при технології “насосних свердловин”. Коефіцієнт вилучення змінився прямо пропорційно від співвідношення Р:Т, так при Р:Т від 0.1 до 2 коефіцієнт вилучення зростає від 1 до $87 \%$.

Практична значимість. Розроблено нову технологію видобутку урану методом підземного свердловинного вилуговування, яка відрізняється низькими капітальними витратами й собівартістю підземного свердловинного вилуговування урану.

Ключові слова: уран, вилуговування, свердловина, вилучення

\section{Совершенствование технологии добычи урана}

в условиях высоконапорного характера подземных вод

\section{Е. Омарбеков, Х. Юсупов}

Цель. В условиях высоконапорного характера подземных вод обосновать технологические решения добычи урана методом подземного скважинного выщелачивания.

Методика. Анализ горно-геологических условий месторождения, проведение опытно-промышленных работ на экспериментальном блоке, обработка данных результатов исследований. Для повышения эффективности и снижения затрат на подземное скважинное выщелачивание урана с учетом гидрогеологических особенностей месторождения были проведены экспериментальные работы с применением технологии “насосных скважин”.

Результаты. Предлагаемая технология приводит к снижению затрат на закупку кабельной продукции, погружных насосов (стоимость более мощного насоса намного меньше, чем стоимость нескольких, равных ему по мощности), на сооружения оголовников скважин. Получены зависимости изменения содержания урана в продуктивном растворе и коэффициента извлечения от соотношения Ж:Т (жидкого к твердому) при технологии “насосных скважин” с изменением Ж:Т от 0.1 до 0.33 , содержание урана в продуктивном растворе выросло с 5 до 225 мг/л, затем наблюдается его плавное снижение. Изменение Ж:Т от 0.9 до 2.2 приводит к незначительному изменению содержания урана до 100-120 мг/л.

Научная новизна. В результате проведенных исследований получены зависимости изменения содержания урана в продуктивном растворе и коэффициента извлечения от соотношения Ж:Т при технологии “насосных скважин”. Коэффициент извлечения изменился прямо пропорционально от соотношения Ж:Т, так при Ж:Т от 0.1 до 2 коэффициент извлечения возрастает от 1 до 87\%.

Практическая значимость. Разработана новая технология добычи урана методом подземного скважинного выщелачивания, которая отличается низкими капитальными затратами и себестоимостью подземного скважинного выщелачивания урана.

Ключевые слова: уран, выщелачивание, скважина, извлечение

\section{Article info}

Received: 6 December 2019

Accepted: 14 August 2020

Available online: 4 September 2020 